\title{
WD Repeat-Containing Protein 26 Measurement
}

National Cancer Institute

\section{Source}

National Cancer Institute. WD Repeat-Containing Protein 26 Measurement. NCI

Thesaurus. Code C127637.

The determination of the amount of WD-repeat containing protein 26 present in a sample. 